\title{
Homeless persons and villages: drugs, social marginalization, and territory of care
}

\author{
Pessoas em situação de rua e as aldeias: drogas, marginalização social e território de cuidado \\ Personas sin hogar y aldeas: drogas, marginación social y territorio de atención
}

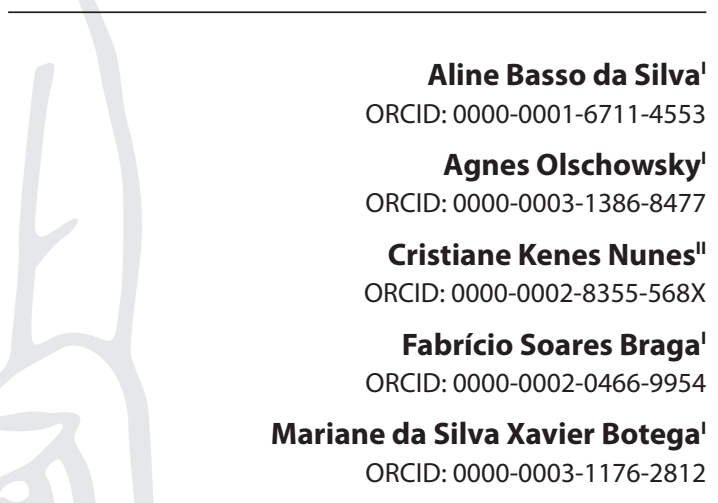

'Universidade Federal do Rio Grande do Sul. Porto Alegre, Rio Grande do Sul, Brazil.

"Prefeitura Municipal de Canoas. Canoas, Rio Grande do Sul, Brazil

How to cite this article:

Silva AB, Olschowsky A, Nunes CK, Braga FS,

Botega MSX. Homeless persons and villages: drugs, social marginalization, and territory of care.

Rev Bras Enferm. 2020;73(Suppl 1):e20190225. doi: http://dx.doi.org/10.1590/0034-7167-2019-0225

\section{Corresponding author:}

Aline Basso da Silva

E-mail:alinee_basso@hotmail.com

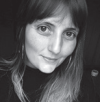

EDITOR IN CHIEF: Antonio José de Almeida Filho ASSOCIATE EDITOR: Andrea Bernardes

Submission: 06-17-2019 Approval: 06-10-2020

\begin{abstract}
Objective: to recognize villages as territories of care and daily resistance to social marginalization. Methods: a descriptive study with a qualitative approach based on the methodological framework of ethnography inspired by Interpretative Anthropology. Two-year field research (from the second half of 2015 to the first half of 2017). Participant observation and semi-structured interviews with four privileged interlocutors and a field diary have been used. Data systematization was carried out throughout field work. Results: three categories emerged: Interlocutors talking about their life in villages; Villages as a care device; and Drugs in villages. Final considerations: the results reveal the challenge for health and nursing to recognize the need to understand the contexts of urban life of homeless persons. Nurses need to include cultural elements in their work processes, promoting bonding and understanding the ways of life of homeless persons.
\end{abstract}

Descriptors: Homeless Persons; Drug Users; Psychiatric Nursing; Anthropology, Cultural; Social Marginalization.

\section{RESUMO}

Objetivo: reconhecer as aldeias como territórios de cuidado e resistência cotidiana à marginalização social. Métodos: estudo descritivo, de abordagem qualitativa, apoiado no referencial metodológico da etnografia inspirada na Antropologia Interpretativa. Pesquisa de campo de dois anos (do segundo semestre de 2015 ao primeiro semestre de 2017). Utilizou-se observação participante, entrevista semiestruturada com quatro interlocutores-privilegiados e diário de campo. A sistematização dos dados foi realizada durante todo o trabalho de campo. Resultados: divide-se em três categorias: Os interlocutores falam sobre a vida nas aldeias; As aldeias como dispositivo de cuidado; e As drogas nas aldeias. Considerações finais: os resultados revelam o desafio que é para a saúde e a enfermagem reconhecerem a necessidade de entender os contextos de vida urbana das pessoas em situação de rua. $O$ enfermeiro necessita abranger elementos culturais em seus processos de trabalho, promovendo vínculo e compreensão dos modos de vida das pessoas em situação de rua.

Descritores: Pessoas em Situação de Rua; Usuários de Drogas; Enfermagem Psiquiátrica; Antropologia Cultural; Marginalização Social.

\section{RESUMEN}

Objetivo: reconocer a los pueblos como territorios de atención diaria y resistencia a la marginación social. Métodos: estudio descriptivo, con enfoque cualitativo, apoyado por el marco metodológico de la etnografía inspirado en la antropología interpretativa. Investigación de campo de dos años (desde la segunda mitad de 2015 hasta la primera mitad de 2017). Se utilizó observación participante, entrevistas semiestructuradas con cuatro interlocutores privilegiados y un diario de campo. La sistematización de los datos se realizó a lo largo del trabajo de campo. Resultados: se divide en tres categorías: Los interlocutores hablan de la vida en los pueblos; Los pueblos como dispositivo de cuidado; $y$ Las drogas en los pueblos. Consideraciones finales: los resultados revelan el desafío para la salud y la enfermería de reconocer la necesidad de comprender los contextos de la vida urbana de las personas sin hogar. Las enfermeras deben incluir elementos culturales en sus procesos de trabajo, promoviendo lazos y la comprensión de las formas de vida de las personas sin hogar.

Descriptores: Personas sin Hogar; Consumidores de Drogas; Enfermería Psiquiátrica; Antropología Cultural; Marginacion Social. 


\section{INTRODUCTION}

Homeless persons are a heterogeneous social group that has been strongly linked to the issue of drug use and crime. Their main characteristics are weakening or inexistence of family ties and regular conventional housing; informal work; and living in degraded urban areas or overnight accommodation units on a temporary basis. Moreover, they are considered vulnerable groups due to their socioeconomic status, stigma, discrimination and violence (social vulnerability). They have the right to reduced social participation because they face barriers to access health services, social assistance, school, and employment (programmatic vulnerability) $)^{(1-2)}$.

In Brazil, there are no official data on the homeless population, however there are a variety of studies with different methodologies to estimate the number of homeless persons. The Institute for Applied Economic Research (Instituto de Pesquisa Econômica Aplicada, abbreviated IPEA), for instance, used the data available in the Unified Social Assistance System Census (Censo do Sistema Único de Assistência Social), conducted in 1,924 cities, to estimate the homeless population in all Brazilian municipalities. IPEA computed that, in Brazil, there are 101,854 people in this situation; two fifths (40.1\%) live in municipalities with more than 900 thousand inhabitants; more than three quarters (77.02\%) live in large cities, with more than 100 thousand inhabitants; and 6,757 homeless persons $(6.63 \%)$ inhabit the 3,919 municipalities with up to 10,000 inhabitants ${ }^{(3)}$.

Drugs are in this set of elements that characterize the life context of homeless persons. Since it is highly perceptible, through the conduct seen in open scenes of drug dealing and consumption, crack has acquired an important magnitude for the media. The media emphasize and expand the dissemination by adding the abusive consumption of this drug to the sectors of youth and the poor of society, such as the homeless population. Thus, the condition of vulnerability and the perception of insecurity by segments of this population expands ${ }^{(4)}$.

Actions are characterized as hygienist and assistentialist in the health field. They do not recognize and understand the street as a cultural territory, of power and identity. For instance, homeless persons are associated with crime or the disease model that sees drug use as a risk for addiction. It is up to users to request treatment and rehabilitation for a biological disease whose only possible instrument would be total abstinence to achieve an ethical and moral value. However, drug use is associated with the existence of subjectivity, desires and identities, and its purely biological effect cannot be assessed ${ }^{(5-6)}$.

As a way of resisting the social world that produces marginalization and deficient public policies, homeless persons, from their relationships, build collectives that allow them to transform and reconfigure the social reality in which they live, building a territory of care $^{(7)}$. The street, in addition to a home space, is where these people carry out informal jobs such as car keepers, cargo unloaders, garbage diggers, among others. Furthermore, it is a territory of affection and protection to overcome the difficulties of living with few resources and the stigmas suffered. For them, the street is not such a threatening place, as their relationships, identities and social organizations develop there ${ }^{(8)}$.
In this study, the street is considered a territory, and is defined by the concept of a multidimensional space of power; not only political, but also economic, symbolic, cultural and natural power. Being a place of power, territorialities are the individual's movements and relationships with his space to control people, phenomena and relationships, marking cultural identities and symbolic appropriations ${ }^{(9)}$.

Emerging health and nursing challenges are considered for care and public policies that take into account the diversities and cultures of homeless persons; and vulnerability understood as multidimensional, depending on numerous sociocultural factors and relationships that are not limited to drug use $\mathrm{e}^{(10)}$. This theme is of great relevance, since it deconstructs the stigma that the homeless population suffers from being socially recognized as drug users and criminals. This theme proposes, in contrast, to recognize that villages should be assumed as territory of care through knowledge of the ways and life experiences of homeless persons.

Considering the need to invest in research that collaborates in the training and qualification of critical professionals, capable of problematizing the issue of homeless persons and drug use and considering it essential that these themes are not disconnected from the contexts of cities and territories of life to which homeless persons create their stories, their relationships and their uses, the following question guided the research: how do villages, from homeless persons and their relationships, constitute a territory of care and resistance to social marginalization?

\section{OBJECTIVE}

To recognize villages as territories of care and daily resistance to social marginalization.

\section{METHOD}

\section{Ethical aspects}

The research project was approved by an ethics committee at Universidade Federal do Rio Grande do Sul (UFRGS). Ethical and legal precepts were respected in research conducted with human beings, according to Resolution 466, of December 12, 2012. This Resolution governs the right to voluntary participation and withdrawal at any time during data collection. It is also based on Resolution 510 of April 7, 2016 of Human and Social Sciences, which provides for specificities in their conceptions and research practices.

\section{Type of study and theoretical-methodological framework}

This is a descriptive study with a qualitative approach based on the methodological framework of ethnography. The ethnographic method aims to access many interpretive layers of social life, aiming at a broad understanding of the phenomena through a process that aims to address macro and microstructural elements ${ }^{(11)}$.

The ethnography used was inspired by Interpretative Anthropology, which aims at a dense analysis of the results, seeking meanings. The dense description meets the researcher's ability 
to make bonds, interact together with the researcher's emotions and concerns in working with this reality with sensitivity ${ }^{(12)}$.

\section{Methodological procedures}

\section{Study setting}

We carried out a field research, knowing the reality of street life, care and drug use in the city of Porto Alegre, state of Rio Grande do Sul. This city has an estimated average population of $1,481,019$ inhabitants, and the area of the territorial unit is $496,682 \mathrm{~km}^{2}$, being a large city, with nearby medium cities called the metropolitan region ${ }^{(13)}$.

\section{Data source}

Throughout fieldwork, there were different interlocutors coming from the spaces of the Brazilian National Street Population Movement, events, conferences and shared meetings. Those who were part of the ethnographic monitoring were called privileged interlocutors. These were selected on purpose, if they lived or had lived on the street for at least one year; use/have used drugs (alcohol and other drugs) for at least one year and be over 18 years old. For this article, information from interviews and observations directly with the four privileged interlocutors were used.

\section{Data collection and organization}

Data collection took place over two years (second half of 2015, 2016 and first half of 2017). This fieldwork was composed by observation of macrosocial structures through the Brazilian National Street Population Movement and microsocial structures through the interlocutors' stories and trajectories. Regarding microsocial structures, the process was called ethnographic monitoring, which reveals the relationship and link between researcher and interlocutor, modifying the instruments according to the interlocutors' particularities.

Participant observation occurred in all meetings with the research interlocutors, guiding the entry into the field and the observation of interactions in the group. Each field visit was recorded in detail in the daily field tool that supported the field observations, giving visibility to the dynamics and the territories experienced ${ }^{(14-15)}$.

The semi-structured interview was based on an initial question: "Tell me about your life story". From the narrative, questions were inserted that deepened the research object based on the following themes: drug use, relationships, territory, ways of life and care. All individual interviews were recorded, and were only made after there was a link between the researcher and the interlocutor.

Data systematization was carried out throughout the fieldwork. In the first stage, the initial organization of the raw data was carried out, indicating paths and main themes to be discussed in the analysis and interpretation of the results in the other stages ${ }^{(15)}$.

\section{Data analysis}

Analysis and interpretation of the results are the improvement of the systematization in order to build the final product, which is the research report ${ }^{(15)}$. In this context, fieldwork has two distinct phases: "being there", which reveals the experience of being in the field and "being here", which reflects the distance from the field to carry out the dense description of the final report/ethnography ${ }^{(12)}$.

In "being there", data collection was carried out using the research instruments, mapping the territories experienced, creating bonds and sharing experiences. To validate the interpretations addressed in the final report, the researcher debated with the interlocutor her observations/interpretations that she idealized during the research. In "being here", it is understood that understanding reality needs to be presented; dense enrollment is an in-depth analysis of the entire research process, which requires isolation of the researcher from the research field.

\section{RESULTS}

We addressed the following categories immersed in the experience between researcher/interlocutor: Privileged interlocutors, in which characteristics of the research participants are presented; Interlocutors talking about their life in villages, in which the community is approached on the street composed of rules, relationships and ways of life of homeless persons; Villages as a care device, in which participants cite the difficulty of accessing formal assistance networks, finding their territories of care in communities on the street; and Drugs in villages, where there are reports on how drugs are part of the ways of life in the village and their habits of collective living in this social space.

\section{Privileged interlocutors}

João, 42 years old, black, tall, has lived in a shelter for homeless persons who have health problems, and his street experience is 20 years. He uses crack, marijuana and alcohol, and his desire is to get off the streets and no longer use drugs. To this end, it has access to the assistance and health network.

José, 38 years old, black, medium height, has lived on the street for 13 or 15 years. Uses alcohol and marijuana. Unlike João, his desire is to continue on the streets.

Jorge, 48 years old, white, thin, has lived on the street for 10 years. The main drug used is alcohol. He says he feels good living on the street and would like to use less alcohol.

Ronaldo, 39 years old, black, has lived on the street for about 10 years. He is a university student and lives in a rented house with other former homeless persons. He uses crack, marijuana and alcohol, considering it to be "normal". He states that drug use is not the main problem of his life.

\section{Interlocutors talking about their life in villages}

There are several places like squares, viaducts, more retired places, I've lived in several places. They used to embrace you more, but today it is different, you have to arrive there with the criminal record papers; depending on the mess you made, they won't let you sleep at the village. Most villages are organized, there are guys who cook, those who harvest water, firewood. Whoever makes the village is the one who lives, there are rules, 'don't come in my shack', blah, blah, blah, everything has a rule. Usually when something happens and we talk, and it didn't work out, we ask to leave. (José) 
Villages work like this: if you do nothing, get a meat, a bean, you will have to do something else, or wash dishes, cut firewood, clean up, sweep; some go after the food and others fix the other things. Wherever are we, we do it. There's the little stove, there's their pots [...]. (João)

It's a community on the street, and you have to do things, you won't eat if you don't do things. Only those who helped, then those who arrive later will only eat if they are left. Because there are street laws [...]. (João)

When the police are going to remove people from the street. One thing is getting one person, but getting five, ten, is another. It is already a problem, if you have five you are already better prepared. It's a way of resisting too. (Ronaldo)

We feel more protected when they are fixed people. It's really cool because we can organize ourselves in terms offood, it's easier in that part, because one brings something, another brings another. (Jorge)

\section{Villages as a care device}

There is no place for everyone in the hostel, when will they manage? There is no space for everyone in the assistance. If you look at the data now, the vacancies do not reach 600. There are 1,000 and something, what do you do with others? The village and the street are the option. (Ronaldo)

There are no devices for everyone there, they end up creating protocols that those who access the shelters are the people who have a health problem. If you can protect yourself, the State does not need to protect you. The State does not want to invest if the person has other possibilities. They want to give you a broom to sweep or a vest to "take care" of the car. Earn a few pennies from those who think it is work or leave you in these recycling sheds in the villages. People talk a lot about anarchism, the figure that is more anarchist are the homeless, but they don't even know, they don't even care about the State, they do things at their pace, in their time, there has to be a great organization on the street. It's not easy. (Ronaldo)

It is not just the drug issue. The street people have a friendship. These days I went to Marcelo's village to deliver something, and he said that if I had nowhere to stay, I could stay there. Somehow, they protect themselves. (Ronaldo)

\section{Drugs in villages}

There are certain villages that use drugs and others that don't ... just harm reduction, which is marijuana in our view. The person who does not use drugs is not close to drug addicts, if you do not use drugs they talk to you: here we use drugs and we will use them and you will not be able to say anything, because whoever is here uses them. The person is not expelled, but he ends up leaving because he will not feel well in that place. (João)

They use it, but everything is well controlled ... the dude has money to use drugs every day, the dude also has to have money to eat. We eat every day; we cook in the morning and in the afternoon. There are twenty or so people, so it has to be organized. (José)

There is drug use. A colleague took his medicine in the morning, because when he took it in the afternoon, he used chemicals in the afternoon or at night. He has not been treated for four months for spending the night using it, then the time passes and he does not take it. This is basically because of excessive use of chemicals, otherwise he ended up losing the medication prescription. Before, there was nursing at the SOP, which kept the medication, regardless of the time you were going to take it, you don't have it today... if another person saw it in the village, he would even get the medicine [...] we take care of one another in the village. (Jorge)

\section{DISCUSSION}

Jorge, João, José, and Ronaldo cite villages as places of organization, friendship, companionship and space demarcation, i.e., there homeless persons build their territory, roam the city, but return to this place. There is the notion of a way of life on the street, as villages are constituted of territorialities and rituals of belonging, such as drug use, collective life and territories of protection and affection. It is also observed the existence of rules for coexistence.

All aspects of life in the villages described above are related to culture $^{(16)}$, which reflects the paths of the groups, through their forms of social organization, ways of life and symbolisms that demarcate their relationships. In the case of our interlocutors, formation of villages is a way of making the street a lived space, based on affinities with people who have similar ways of life, creation of bonds and rituals in common, including drug use.

Throughout history, villages defined the process of man's relationship with space, being part of the cities. Villages are conceptualized as a small town, with few inhabitants, without administrative autonomy, being a rural community. In the history of mankind, man lived in villages in the Neolithic period, when he stopped being a nomad, seeking better living conditions for fertility, nutrition (from agriculture) and protection through groups of people ${ }^{(17)}$.

The interlocutors' villages are not rural villages, they are communities on the street, i.e., group organizations established in the city. These are territories of power and care, here called daily resistance, as they are also built in order to overcome the adversities of social marginalization.

Homeless persons comprise an extremely heterogeneous segment of social fragility with a high degree of poverty and social marginalization; they are, therefore, immersed in lack of opportunities and conditions of socioeconomic vulnerabilities. Most of the time, they roam the streets, sleep in public and private places, under the rigor of winter or in the heat of summer ${ }^{(18)}$. As much as the street is the only alternative in the face of contexts of social disruption and deficient policies, it ends up being a means of home and work, a place of freedom and prison, of solidarity and prejudice, of survival and resistance.

According to what was observed in the statements, the formal care system has limitations, through barriers of access and insufficiency of hostels, shelters and inclusion policies for these people. Therefore, it is necessary to prepare a care network on the street to give them survival. There is also difficulty in understanding the universe of the street by institutions, showing the neglect of public policies that push the group to life in villages, on the streets or to death.

Vulnerability as a concept is three-dimensional, dealing with individual and relational issues of the subjects. There is individual vulnerability (genetic, physical and psychological, intersubjective 
characteristics), social vulnerability (economic issues, gender, race, culture) and programmatic vulnerability (access to policies, services, care actions) ${ }^{(10)}$.It is observed in this study that, in practice, the group of homeless persons points out the complexity of their lives on the streets. At the same time, these people recognize their weaknesses in the face of the system, the policies that stigmatize and marginalize them. Villages can be an option to not die alone on the streets (which is not only positive), as there are also their opinions and perceptions of being strengths and resistances, i.e., living collectively in villages can reduce their individual and social vulnerabilities. In this way, the construction of their perceptions about being or not "vulnerable" are not watertight, and there is no consensus that they are in a permanent "state of vulnerability".

The studied population inhabits the streets and uses alcohol and other drugs, but it does not mean that they are totally taken by these substances, without any control over their individual and health needs; and, therefore, are subject to intervention, be it in the health or social order. By participating in the daily lives of the interlocutors, it was possible to perceive the multiplicity of uses they make, from alcohol to crack and their strategies for obtaining them; the acquisition of food and other survival resources.

Thus, drugs appear in life in villages, but they are not the main element, as stated by João and Ronaldo. João says that there are villages with their "uses" and others not. Ronaldo reveals that the most important thing in this life is the question of friendship. These reflections lead to the perception of the complexity of drug use on the street, which shows a collective and symbolic character, not only linked to disease and crime.

The arguments corroborate with ethnographic studies that show that drug users considered "heavy" like crack have their practices of self-care and self-control of use and also their survival strategies in society, such as working on the street, which depends on their physical effort diary. This demonstrates relationships beyond chemical dependence, seeking to broaden the understanding of the topic. Thus, it is necessary to visualize the social, contextual and individual variables and not only substance use ${ }^{(19)}$.

This study adds new elements to think about the drug care process, recognizing the context of the street to reflect on the culture and experience of marginalized groups. This is pointed out in the narratives of the interlocutors who demonstrate that they live the street territory intensely, i.e., they influence and are influenced by it. While for the rest of society, the street is perceived as a place of passage between their homes, work and leisure spaces, among others, for homeless persons, because they exist in it, influence this territory through all their actions of life (social organization, work, leisure, coexistence). At the same time, they are influenced by it, as they are not spaces of passage, but rather relational, care and survival territories.

When recognizing the influences on the territory, the villages are understood as spaces lived and transformed in a symbiotic way (cultural, political, economic). Villages are a field of lived dimensions, ordinary spaces of everyday life, which sometimes do not even realize the limits and boundaries between different possibilities of territorial constructions ${ }^{(20)}$. Therefore, the interlocutors point to a territory that promotes care, as it is a meeting device, a place of desires, dreams and needs for a better life, addressing the protection and relationship created between groups between groups through collectivity, division of tasks and responsibilities, creating bonds of friendship. Moreover, the way of life on the street can be more difficult when lived individually, which is addressed by one of the interlocutors: "When the police are going to remove people from the street. One thing is getting one person, but getting five, ten, is another".

Villages as "places of life" are also a field of resistance, where people stigmatized and expelled from normal society create spaces for identification, codes, norms and strategies for survival(21). Marginalized and hidden groups in society make it possible to find alternatives for caring for oneself and the body, build bonds and social interactions that enhance exchange of knowledge about drugs, the street, pleasures, fears, rights, and belonging ${ }^{(22)}$.

Accelerated urbanization, together with the productive force of the proletariat and the poor, was essential for the development of cities, creating the idea of the body as a work force, which is biological and individual. Considering all aspects of individual needs requires the adoption of a broader health concept capable of overcoming the biological dimension and enabling the construction of health strategies that aim to intervene in the problems and determinants related to the health-disease process ${ }^{(23)}$.

Understanding the life, choices and health problems of the homeless population does not solve inequality and social marginalization; nor does the Federal Constitution, with its articles providing social rights, guarantee the most universal and equitable public policies for the population; although the Brazilian Health System (Sistema Único de Saúde) is the most important landmark of public health policies, specific policies for the homeless population must be built based on the principle of integrality by strengthening intersectorality.

The homeless population has very precarious social and health conditions, including with regard to basic and constitutional social rights. Lack of access to the formal labor market, education, health services and other public services favors the construction of negative images in relation to these social groups. Denial of rights and production of more stigma, prejudice and marginalization generate a vicious circle; and overcoming depends on being able to break the barrier of the known, assuming attitudes of tolerance and respect for differences ${ }^{(24)}$.

In line with this, a study that studied the "psychotropic territories" in the city of Porto Alegre, showed that hygienist actions, which expel homeless persons from the territories, increase the difficulty of access of health professionals to this population. The effects of these actions are clearly felt in the local circuits of use and sale of crack, which are spread to contiguous areas of less visibility. As a result, health teams, especially those in primary care, find it difficult to develop their work proposals because they are unable to concentrate enough people for the intended actions. Furthermore, among the survival strategies used by the observed subjects, there was no direct relationship between using crack and being the protagonist of violent acts, an association of common sense seen in society ${ }^{(19)}$.

The importance of embracing homeless persons as subjects of rights and bearers of a singular life trajectory is emphasized and, thus, meeting their demands; considering the needs imposed by life on the street, the establishment of a bond between homeless persons and the actors involved in care; and overcoming the 
distance resulting from social discrimination that hinders the accessibility of this population to health services ${ }^{(25)}$.

These people are clearly visible as occupants of public places. But their bodies become invisible as individuals with suffering caused by contemporary transformations, strangeness and rejection, as if they did not belong to that space ${ }^{(26)}$. Therefore, one does not look at people in public spaces, one looks at spaces that unite homeless persons and their "damning" practices, "no man's land" where there are no rules. Where, therefore, anything can happen, or rather, in "crack land", where nothing good can happen, since it is a space where crack is the "sovereign"(27).

However, by showing their marginalized and homeless bodies in these public places, they become political actors who reveal the injustice hidden within society, as well as the need to recognize the plurality and complexity of these human lives ${ }^{(26)}$. The voices of Jorge, João, José and Ronaldo allow us to have contact with their realities and their conceptions as political beings who assess aspects of their existence and also the weaknesses of institutions that should serve them. It is observed that despite their visibilities for being and living on the street, they are still invisible by a society, institutions and professionals who do not want to understand their different cultures. However, listening to these life stories also announces the other side of this territory, as there are still groups, which even in the midst of accelerated urbanization, propose the group/collective way of life as power, survival, and daily resistance.

Despite the contradictions, the visibility of being on the street is kept invisible, as the voices and life stories of these people are often silenced. Such stories, when heard, show the other side of this territory, as they still live in groups as a way of survival and daily resistance.

The social organization of this group reveals, in addition to a place of friendship, perception of oneself and the other, of experiences, cultures and values, a territory that imposes rules and copes with vulnerabilities. This organization can be different from other population groups, which generates the stigma and stereotype of "bum". However, living on the streets requires greater social organization for survival, which means that the rhythms of homeless persons different from the city's customs are ways constructed and recognized among them.

There are different forms of territory that can be seen separately or in motion. There is the policy that refers to a territory marked and delimited by the power of the State. There is the economy that reflects a territory as a source of resources, and the relationship between capital and labor. There is also the cultural that addresses a marked space of relations between the community or the social group, being a space lived and transformed by social groups ${ }^{(28)}$.

The territory of daily resistance of the street population meets the idea that addresses a territory of symbiotic dimensions (cultural, political, economic). It is a field of lived dimensions, ordinary spaces of everyday life that, at times, do not even notice the limits and boundaries between different possibilities of territorial constructions ${ }^{(26)}$.

Unlike the notion of fragility, it can be said that vulnerability and resistance are concepts that "go together". From the situations of vulnerability experienced by people, coping strategies emerge. In this way, villages are a way of resisting situations of vulnerability resulting from being a person on the street. Villages reconfigure a territory seen as infertile, transforming it into a territory of care $^{(29)}$.

Thus, the idea can be related to the notion of "communitarianism" of minorities. Community life occurs more naturally when people are denied the right to be part of the whole, of society (assimilation). These people are left with the stigma and their "alien" origins from a different community than the "normal" ones. They then come together to share this same experience of rejection, seeking shelter in the supposed "fraternity" of a native group as an option ${ }^{(30)}$.

Furthermore, it is important to differentiate the notion of place and territory. Place first refers to the experience of man with space, in which space comes to mean culture, values. Territory is more closely related to the question of power and dominance, in which this individual, or group, is identified, either by the documents, by the rules of coexistence, domination of the living space and common coexistence ${ }^{(28)}$.

Villages are places and territories, as they express symbiotic dimensions of a subjective, cultural, political and power character. The notion of affection is also an overcoming of the adversities and institutional violence of capitalism. The subjects need to organize themselves in networks on the street, with their rituals and rules to overcome a system contrary to their ways of life. In these systems created by the group, the drug is a common and cultural ritual.

The ethnographic data covered in this article speak of people with life histories that reflect the importance of health professionals to cast their eyes on the universe of marginalization and the needs of street populations. Knowing that villages exist and understanding the contexts of the people who inhabit them can contribute to the awareness of health and nursing professionals. As pointed out in Jorge's speech, when indicating nurses as agents of care, the simple action of storing medications was in accordance with a practice that reduced the risks of homeless persons. This helps to understand the relevance of work centered on cultural elements, according to the ways of life, seeking to promote equity, integrality and humanization in the health of homeless persons.

\section{Limitations of the Study}

In the initial composition, it was the researcher's interest, that in addition to male participants, that there was also the participation of women as privileged interlocutors, which was not possible. It is understood that this fact occurred due to the gender issue being configured as a greater vulnerability "on the street". Homeless persons are discriminated against because drug use is an illegal practice and because some homeless persons have legal and family disputes. Thus, it is understood that women suffer even more from the issues exposed; and maybe it is the reason for not accepting to participate in the research, making it a limitation not to hear their social realities in this study.

\section{Contributions to the Field}

This study could broaden the debate on drugs and social diversity and vulnerabilities, in addition to hegemonic conceptions 
centered on chemical and biological dependence; it can broaden the understanding of care beyond the symptom of the disease, including ways of life, cultures, social relationships and the processes that imply the creation and development of society. From this perspective, nursing can move forward to contribute to the creation of public policies, work strategies and changes in care models that consider subjectivities and socio-cultural issues in health care.

\section{FINAL CONSIDERATIONS}

The results of this article point to the challenge of recognizing the need to understand the contexts of urban life of homeless persons as a challenge for health and nursing. For care related to drug use, it is necessary to know the reality of people's lives and perceive their territories as spaces of identities, cultures, power and coping with vulnerabilities through mutual support built by the group.

Drug use is characterized in the collective; it is a way of life and social organization that encompasses stories and social relationships, deconstructing individual use that results in physical dependence on the drug in the body. Drugs are not the main element that guides living on the street, as they are part of life situations in villages: organization of groups to resist marginalization, affection, friendship, difficulty accessing programs, services and policies.

Finally, qualitative research through ethnography to know and deepen complex topics such as drugs on the street are important. Thus, it is possible to establish bonds and relationships with the interlocutors for a better understanding of their realities. It also points out the need for further social and qualitative studies in health that analyze the issue of drugs and the street, in addition to stigmas and conceptions focused only on the disease.

\section{FUNDING}

This research was funded by the Coordination of Support to Higher Education Personnel (Coordenação de Apoio ao Pessoal de Nível Superior, abbreviated CAPES) through a doctoral scholarship in the country.

\section{REFERENCES}

1. Xavier MP, Lima CF, Prado GAS, Oliveira TF. Pessoas em situação de rua: saúde, território e cuidado. Mnemosine [Internet]. 2019 [cited 2020 Mar 23];15(2):125-37. Available from: https://www.e-publicacoes.uerj.br/index.php/mnemosine/article/view/48320/32248

2. Santos CS, Wanderbroocke ACNS, Tagliamento G. Senses of the psychosocial support network for homeless people Salud Soc. 2018;9(3):282-293. doi: 10.22199/S07187475.2018.0003.00006

3. Natalino MAC. Estimativa da população em situação de rua no Brasil. Texto para discussão. Instituto de Pesquisa Econômica Aplicada - IPEA. Brasília: Ipea; 2016. 36 p.

4. Toledo L, Góngora A, Bastos, FIPM. À margem: uso de crack, desvio, criminalização e exclusão social - uma revisão narrativa. Ciênc Saúde Coletiva. 2017;22(1):31-42. doi: 10.1590/1413-81232017221.02852016

5. Acioli ML, Santos MFS. Os usos de crack em um contexto de vulnerabilidade: representações e práticas sociais entre usuários. Psi.: Teor Pesq. 2016;32(3):e32326. doi: 10.1590/0102-3772e32326

6. Teixeira MB, Ramôa ML, Engstrom E, Ribeiro JM. Tensions between approach paradigms in public policies on drugs: an analysis of Brazilian legislation in 2000-2016. Ciên Saúde Coletiva. 2017;22(5):1455-66. doi: 10.1590/1413-81232017225.32772016

7. Oliveira DM, Expedito AC, Aleixo MT, Carneiro NS, Jesus MCP, Merighi MAB. Needs, expectations and care production of people in street situation. Rev Bras Enferm. 2018;71(Suppl 6):2689-97. doi: 10.1590/0034-7167-2017-0612

8. Curvo DR, Matos ACV, Sousa WL, Paz ACA. Integralidade e clínica ampliada na promoção do direito à saúde das pessoas em situação de rua. Cad Bras Saúde Mental [Internet]. 2019 [cited 2019 Mar 14];10(25):58-82. Available from: http://incubadora.periodicos.ufsc.br/index.php/ cbsm/article/view/5025/5204

9. Haesbaert R. O Território e a nova Des-territorialização do Estado. In: Dias LC, Ferrari M, (Org.). Territorialidades Humanas e Redes Sociais. Florianópolis: Insular; 2013. p. 19-37.

10. Ayres JRCM. Prevenção de agravos, promoção da saúde e redução de vulnerabilidade. In: Clínica Médica/vol. 1. Barueri, SP: Manole; 2016.

11. Eckert C, Rocha ALC. Etnografia: saberes e práticas. In: Pinto CRJ, Guazzelli CAB(Org). Ciências Humanas: pesquisa e método. Porto Alegre: Editora da UFRGS; 2008. p. 09-24.

12. Geertz C. A Interpretação das Culturas. Rio de Janeiro: LTC; 2008. 224 p.

13. Instituto Brasileiro de Geografia e Estatística. Censo Demográfico 2010: população estimada [Internet]. IBGE; 2016 [cited 2019 Mar 13$].$ Available from: https://cidades.ibge.gov.br/brasil/rs/porto-alegre/panorama

14. Monico L, Alferes V, Perreira P, Castro PA. A observação participante enquanto metodologia de investigação qualitativa. Atas Investigação qualitativa em ciências sociais. CIAlq [Internet]. 2017[cited 2020 Mar 23];(3). Available from: https://proceedings.ciaiq.org/index.php/ ciaiq2017/article/view/1447

15. Yin RK. Pesquisa qualitativa do início ao fim. Série Métodos de Pesquisa. Editora Penso, 2016.

16. Santos JL. O que é cultura. São Paulo: Brasiliense; 2017. 79 p 
17. Sposito MEB. Capitalismo e urbanização. São Paulo: Contexto; 2018. 80 p.

18. Nonato DN, Raio RWG. Invisíveis Sociais: a negação do direito à cidade à população em situação de rua. Rev Dir Urban, Cid Alter. 2016;2(2):81-101. doi: 10.26668/IndexLawJournals/2525-989X/2016.v2i2.1321

19. Raupp L, Adorno RCF. Psychotropic territories in the center of Porto Alegre city, Rio Grande do Sul, Brazil. Saúde soc. 2015; 24(3):803-15. doi: 10.1590/S0104-12902015127672.

20. Crestani AMZ. Revelando lugares e territórios urbanos: espacialidades urbanas e suas sobreposições na cidade contemporânea. Curitiba: Appris; 2014. $197 \mathrm{p}$.

21. Abal YS, Gugelmin SÁ. Aproximações etnográficas em territórios marginais: as cenas abertas de uso do crack em Cuiabá. Civitas, Porto Alegre. 2019;19(1):78-194. doi: 10.15448/19847289.2019.1.30951.

22. Medeiros R, Silva C, Gonçalves L. Sujos, itinerantes e drogados: etnografia sobre vida na rua e uso de drogas. In: Anais. 5 a Reunião Equatorial de Antropologia e 14a Reunião de Antropólogos do Norte-Nordeste, Maceió, 2015.

23. Paiva IKS, Lira CDG, Justino JMR, Miranda MGO, Saraiva AKM. Homeless people's right to health: reflections on the problems and components. Ciênc Saúde Coletiva. 2016;21(8):2595-606. doi: 10.1590/1413-81232015218.06892015.

24. Abreu D, Oliveira WF. Atenção à saúde da população em situação de rua: um desafio para o Consultório na Rua e para o Sistema Único de Saúde. Cad. Saúde Pública 2017;33(2):e00196916. doi: 10.1590/0102-3611X00196916

25. Hallais JAS, Barros NF. Street Outreach Offices: visibility, invisibility, and enhanced visibility. Cad Saúde Pública. 2015;31(7):1497-504. doi: 10.1590/0102-311X00143114

26. Kubota H, Kohlen H, Clandinin DJ, Caine V. Recognizing the body as being political: Considering Arendt's concepts in the context of homelessness in Japan. J Contemp Ethnogr. 2018;48(2):287-305. doi: 10.1177/0891241618783840

27. Silva S, Adorno RCF. Exposição e invisibilidade: as narrativas de usos e controles de drogas consideradas ilícitas. Bol Inst Saúde [Internet]. 2017 [cited 2019 Mar 5];18(1):83-99. Available from: http://www.saude.sp.gov.br/resources/instituto-de-saude/homepage/bis/bis_18_1_ errata_pg_69.pdf.

28. Haesbaert R. O Mito da Desterritorialização: do fim dos territórios à multiterritorialidade. Rio de Janeiro: Bertrand Brasil, 2011.396 p.

29. Carmo ME, Guizard FL. O conceito de vulnerabilidade e seus sentidos para as políticas públicas de saúde e assistência social. Cad Saúde Pública. 2018;34(3):e00101417. doi: 10.1590/0102-311x00101417

30. Costa R. On a new concept of community: social networks, personal communities and collective intelligence. Interface. 2005;9(17):235-48. doi: 10.1590/S1414-32832005000200003 